\title{
Enhancing the Students' Speaking Skill Using Three Step Interview and Numbered Heads Together
}

\author{
Sri Rahayu Ratnawati \\ LKP Nissan Fortuna Kudus, \\ Indonesia \\ Email: \\ ratnarahayunf@gmail.com
}

\author{
Issy Yuliasri \\ English Language Education \\ Pascasarjana Universitas \\ Negeri Semarang, Indonesia
}

\author{
Rudi Hartono \\ English Language Education \\ Pascasarjana Universitas \\ Negeri Semarang, Indonesia
}

Received: 20 October 2017. Revised: 20 January 2018. Accepted: 10 April 2018

\begin{abstract}
This research aimed to investigate the effectiveness of Three Step Interview (TSI) and Numbered HeadsTogether Techniques (NHT) to enhance speaking skill for the students having different motivation levels and to show if there is any interaction between teaching techniques and motivation. The participants of the research were the students of survival English Class Level of Nissan Fortuna English Course, Kudus. The research method of this study was quantitative by using $2 \times 2$ factorial experimental research designs. The data collection was done by giving questionnaire and conducting pre-test and post-test and was analyzed by using ANOVA. This study found that (1) TSI and NHT are effective to enhance speaking skill of students with different motivation level, (2) Enhancing speaking skill of the high motivated students using TSI is more effective than using NHT, (3) Enhancing speaking skill using TSI to the low motivated students is more effective than using NHT, (4) There is no interaction between the techniques and students' motivation. This study concluded that TSI and NHT can be used as techniques to enhance the students' speaking skill no matter how students' motivational level is.
\end{abstract}

Keywords: Cooperative learning, motivation, numbered heads together, speaking, three step interview

How to Cite: Ratnawati, S.R., Yuliasri, I., \& Hartono, R. (2018). Enhancing students' speaking skill using three step interview and numbered heads together. Language Circle: Journal of Language and Literature, 12(2), 173-182.

\section{Introduction}

Speaking is an important skill for English language learners to communicate each other. The English teaching-learning in a non formal education (an English course) has some problems and difficulties for the teachers. Teaching speaking is very important and it requires teachers to be creative to facilitate the students with fun and effective learning activities. Nunan (2003) stated that success is measured in terms of the ability to carry out a conversation in the (target) language. From this statement we can conclude that teaching speaking should be given good attention from English teachers. The teacher of English Course should have some techniques to teach them well. The teachers should be able to make them enjoy learning and create a student-centered atmosphere with different teaching learning techniques so that the learning is fun and interesting. 
TSI is a strategy which gives learners opportunities to repeatedly use their knowledge of the English Language. According to Utami (2010), there are some advantages of using this strategy. Firstly, TSI is a physically active process to activate students' prior knowledge of a topic through conversation that uses language in the process of learning and gives the learner opportunity to practice their speaking. Secondly, the learners will get the same chance to practice their ability of speaking without feel anxious. Thirdly, this strategy will make the situation in the classroom more joyful and can be expected to make the learner more cooperative during the speaking class. Three-Step Interview is one of the cooperative learning strategies that was developed by Spencer Kagan in 1989 which provides the opportunities for students to give the responses in turn. It means that every member in group could have his/her own turn to give the responses based on the material given by the teacher. In this case, the students interview about article that they have read and share what they learned in the interview in the team. The students have to pay attention to the response given by their teammates. Here, the students could listen to the response expressed by their teammates that could get multiple perspectives and may be more open to alternative explanation.

NHT is a cooperative learning strategy that holds each student accountable for learning the material. In this technique each student of each group gets the number and their own tasks, but they should decide the best and the appropriate answer for the group by considering each answer of the members of the group. NHT was developed first by Kagan (1993) to involve more students in learning material which consist in a lesson and to know their knowledge about the material given. Students are placed in a groups and each person is given a number (from one to the maximum number in each group). The teacher poses a question and students "put their heads together" to figure out the answer. The teacher calls a specific number to respond as spokesperson to the group. By having students work together in a group, this strategy ensures that each member knows the answer to problems or questions asked by the teacher. Because no one knows which number will be called, all team members must be prepared. According to Lie (2010, p. 60), there are several steps in implementing NHT, they are: divide the students into groups of four and give each one a number from one to four, pose a question or a problem to the class, have students gather to think about the question and to make sure everyone in their group understands and can give an answer, ask the question and call out a number randomly, the students with that number raise their hands, and when called on, the students answers for his or her team.

Mulyadi (2013) focuses on the relationship between students' preferences regarding PowerPoint and their speaking skills in the accounting classroom learning process. The study was conducted using classroom action research. The results of this study show a significant relationship between students' preferences regarding PowerPoint Multimedia related to their speaking skills as shown in their improvement of post test, rubric of speaking evaluation and positive responses of students. Students can make an attractive presentation using power point in English. However, the research, that the writer conducted, differs from the previous one. First, if the previous one used classroom action research as research method while this research used experimental research. Second, 
the previous used multimedia, while this research used techniques (Numbered Heads Together and Thre Step Interview).

Another similar research was conducted by Darsini (2013). Her research showed that Cooperative Learning Method (here she used Three Step Interview and Numbered Heads Together) was able to improve the students' speaking skill. However, the research, that the writer conducted, differs from the previous one. First, if the previous used Junior High School as Subject, this research used the students of an English course as the subject or the research. Second, the previous one used classroom action research as research method while this reseach used experimental research.

Research on speaking had also been conducted by Milchatun, Bharati, \& Hartono (2015). They used the students of the State Institute Islamic Studies Syekh Nurjati Cirebon in the Fourth Semester of the Academic year of 2013/2014 as subjects of research consisted of 30 students. The findings of the research showed that role play technique can improve students" personal self concept in teaching speaking significantly from first cycle to the next cycle. The other finding can be seen from classroom situations, i.e.: during the speaking class the students has courage to express their idea freely, good attention in speaking class, well in discussion term, well in team work, they feel confident with their ability in solving problem, and more creative.

Yuliasri (2017) proved that both of the techniques were effective to enhance descriptive text writing for students of different levels of motivation. However TPS was more effective than CIRC. The result of the study proved that both of the techniques were effective to enhance descriptive text writing for students of different levels of motivation. However, the research, that the writer conducted, differs from the previous one. First, if the objectives of the previous study was to improve teachers' skills while the objective of this research was to enhance students' speaking skill. Second, the previous used Cooperative Learning Techniques, while this research used 2 techniques (Numbered Heads Together and Three Step Interview).

Hidayati (2013) described how roleplay technique improved students' motivation in speaking class. This study was conducted in classroom action research. The research was conducted in the eighth graders at the state junior high school 1 Brebes in the academic year of 2012/2013. The findings showed that the implementation of the role playing technique could improve the students $^{\text {ee }}$ motivation in the aspects of interest, concentration, diligence and satisfaction. However, the research, that the writer conducted, differs from the previous one. First, if the previous one used classroom action research as research method while this research used experimental research. Second, Second, the previous usedthe role playing technique while this research used techniques (NHT and TSI) .

Kartika (2013) described how script paired learning improve students' confidence in speaking English. This technique has successfully done to gain students confidence in speaking class. The finding showed that there were improvements in students' speaking skill and also attitude. However, the research, that the writer conducted, differs from the previous one. First, if the previous one used classroom action research as research method while this research used experimental research. Second, the previous used script paired learning, while this 
research used Numbered Heads Together and Three Step Interview.

A similar study was conducted by Yuliasri (2011). She applied the Cooperative Learning techniques, particularly the Jigsaw and Think-Pair-Share techniques, to help students improve their Indonesian-English translation skill, especially in terms of diction, grammar, and rendering of message/content of text. Her research showed positive results, revealing that the application of Cooperative Learning techniques could improve students' skill in translating. However, the research, that the writer conducted, differs from the previous one. First, if the previous used students of Semarang State University, this research used the students of an English course as the subject or the research. Second, the previous one used classroom action research as research method while this research used experimental research. Third, the previous used Jigsaw and Three Step Interview, while this research used Numbered Heads Together and Thre Step Interview. Beside that the aim of the previous study was to improve translating skill and this research aimed to improve speaking skill.

\section{Methodology}

This study was an experimental research with factorial design. This study aimed to investigate the correlation between cause and effect and how far its correlation by giving certain treatment to the experimental group and giving different treatment to the control group as the comparison. The cause and effect in this study were compared between the two groups. The students of each class were divided by considering their levels of motivation; high and low motivation. Thus, this study employed factorial design $2 \times 2$ by the technique of multifactor analysis of variance (ANOVA). This research used quantitative approach. I saw the effectiveness of cooperative learning techniques in teaching speaking, and observed how the use of cooperative learning techniques can give the effects to improve it. I also studied how significance the improvement of students' speaking practice could improve the students' speaking skill.

The research design of this study was a pre-test-post-test control group design. It was constructed in academic year 2015 in Nissan Fortuna Course Kudus. It was conducted in 4 weeks. The subjects of this study were the students of Nissan Fortuna Course Kudus. There were 60 students in this course and the writer used random sampling of five classes as the subject of the research. They were divided into three groups based on their motivation (low, moderate, and high). 24 students were chosen randomly to be the subjects of the research and 60 students were used in tryout of the research instrument the subject that was employed in this study was those low and high motivated students. After determining the groups, then it was determined whether they were homogenious and the data were in the normal distribution. While the location of try out and treatment also was conducted at Nissan Fortuna English Course Kudus in academic year 2015.

The instruments were used as a tool to measure in this study which was conducted through two instruments; motivational scale to measure students' motivation, and pre-post test to measure students' speaking skill.

Instruments used to collect the data were a questionnaire and tests. In order to give scores to students' speaking skill, this research used the scoring rubric by Brown (2004). In order to make the data complete 
the writer is going to describe the experimental design of the experimental group and control group. There were some steps in conducting an experiment which had to be done in a chronological order.

The test of normality and homogenity were analyzed using SPSS. While the differences of pre-test and post-test results between experimental and control group in enhancing the students' speaking skill were

Paired Samples Statistics
\begin{tabular}{|ll|l|l|l|l|}
\hline & & Mean & $\mathrm{N}$ & $\begin{array}{c}\text { Std. } \\
\text { Deviation }\end{array}$ & $\begin{array}{c}\text { Std. Error } \\
\text { Mean }\end{array}$ \\
\hline Pair 1 Post Exp High & 76.6667 & 6 & 7.58288 & 3.39116 \\
& & & & \\
& Post Cont High & 70.8333 & 6 & 7.58288 & 3.39116 \\
\hline & & & & \\
\hline
\end{tabular}
Mariance). ANOVA is a collection of
Statistical models used to analyze the
differences between group means. To
conduct an ANOVA, it can be calculated by
using SPSS. Thus, this study employed SPSS
to measure the ANOVA.

\section{Findings and Discussion}

These are the main results detailed in this

Paired Samples Test

\begin{tabular}{|c|c|c|c|c|c|c|c|c|}
\hline \multirow{4}{*}{$\begin{array}{c}\text { Post } \\
\text { Exp } \\
\text { High }- \\
\text { Post } \\
\text { Cont } \\
\text { High }\end{array}$} & \multicolumn{5}{|c|}{ Paired Differences } & \multirow[b]{3}{*}{$\mathrm{T}$} & \multirow[b]{3}{*}{ df } & \multirow{3}{*}{$\begin{array}{c}\text { Sig. } \\
(2- \\
\text { tailed) }\end{array}$} \\
\hline & \multirow[b]{2}{*}{ Mean } & \multirow{2}{*}{$\begin{array}{c}\text { Std. } \\
\text { Deviation }\end{array}$} & \multirow{2}{*}{$\begin{array}{l}\text { Std. } \\
\text { Error } \\
\text { Mean }\end{array}$} & \multicolumn{2}{|c|}{$\begin{array}{l}95 \% \text { Confidence } \\
\text { Interval of the } \\
\text { Difference }\end{array}$} & & & \\
\hline & & & & Lower & Upper & & & \\
\hline & $2.00000 \mathrm{E} 1$ & 9.35414 & 4.18330 & 8.38530 & 31.61470 & 4.781 & 4 & .009 \\
\hline
\end{tabular}

article. the effectiveness of TSI compares to NHT to enhance speaking skill for the students having high motivation, the effectiveness of TSI compares to NHT to enhance speaking skill for the students having low motivation, there is any interaction between teaching techniques and motivation in the survival English Class of the students at Nissan Fortuna English Course of Kudus.

Based on the findings, in general, the discussion goes to explain the effectiveness of TSI and NHT as techniques to teach speaking to students with high and low motivation. The result of the analyses is as follow:

\section{Mean Score of Post Test for HighMotivated}

Paired Samples Test

\begin{tabular}{|c|c|c|c|c|c|c|c|c|}
\hline \multirow{4}{*}{$\begin{array}{c}\text { Post } \\
\text { Exp } \\
\text { Low } \\
\text { Post } \\
\text { Cont } \\
\text { Low }\end{array}$} & \multicolumn{5}{|c|}{ Paired Differences } & \multirow[b]{3}{*}{$\mathbf{T}$} & \multirow[b]{3}{*}{ df } & \multirow{3}{*}{$\begin{array}{l}\text { Sig. (2- } \\
\text { tailed) }\end{array}$} \\
\hline & \multirow[b]{2}{*}{ Mean } & \multirow{2}{*}{$\begin{array}{c}\text { Std. } \\
\text { Deviatio } \\
\mathbf{n}\end{array}$} & \multirow{2}{*}{$\begin{array}{l}\text { Std. } \\
\text { Error } \\
\text { Mean }\end{array}$} & \multicolumn{2}{|c|}{$\begin{array}{l}\text { 95\% Confidence } \\
\text { Interval of the } \\
\text { Difference }\end{array}$} & & & \\
\hline & & & & Lower & Upper & & & \\
\hline & 1.80000E1 & $\begin{array}{c}10.3682 \\
2\end{array}$ & 4.63681 & 5.12615 & $\begin{array}{c}30.8738 \\
5\end{array}$ & 3.882 & 4 & .018 \\
\hline
\end{tabular}

Students Treated TSI and NHT

Based on the table above, it can be seen that the mean score of post-test for high motivated students treated using TSI was 76.6. While the mean score of post-test for high motivated students treated using $N H T$ was 70.8. It can be concluded that the speaking skill of those treated using Three Step Interview is higher than those using Numbered Heads Together after the treatment. However, to measure whether the difference is significant, it was then measured by using the paired t-test. The result is as follows.

\section{Post-Test Result of High Motivated Students Treated Using TSI and NHT}

From the result above, it shows that the $\mathrm{t}$-count of the both post-test was 4.781 while the $\mathrm{t}$-table is 1.833 . It can be seen that the $\mathrm{t}$ count is higher than the t-table (t-count $>\mathrm{t}$ table). In addition, the sig.value resulted 0.009 which is lower than the $\alpha$ sig. 0.05 (sig.value $<\alpha$ sig. 0.05). Therefore, Ho5 is 
rejected and Ha5 is accepted, which means that there was a significant difference of high

\begin{tabular}{|l|r|r|r|r|r|}
\hline Source & $\begin{array}{c}\text { Type III Sum of } \\
\text { Squares }\end{array}$ & df & Mean Square & F & Sig. \\
\hline Corrected Model & $1815.000^{\mathrm{a}}$ & 3 & 605.000 & 10.876 & .000 \\
Intercept & 132845.000 & 1 & 132845.000 & $2.388 \mathrm{E} 3$ & .000 \\
Techniques & 1805.000 & 1 & 1805.000 & 32.449 & .000 \\
Motivation & 5.000 & 1 & 5.000 & .090 & .768 \\
Techniques * & 5.000 & 1 & 5.000 & .090 & .768 \\
Motivation & 890.000 & 16 & 55.625 & & \\
Error & 135550.000 & 20 & & & \\
Total & 2705.000 & 19 & & & \\
Corrected Total & \multicolumn{2}{|l}{} \\
R Squared = ,671 (Adjusted R Squared =,609)
\end{tabular}

motivated students treated using TSI and NHT.

Mean Score of Low Motivated Students Treated Using TSI and NHT

Based on the table above, it can be seen that the mean score of post-test for low motivated students treated using TSI was 79.1. While the mean score of post-test for low motivated students treated using NHT was 70 . It can be concluded that the speaking ability of those treated using THI is higher than those using NHT after the treatment. However, to measure whether the difference is significant, it was then measured by using the paired t-test. The result is as follow.

\section{Post-Test Result of Low Motivated Students Treated Using TSI and NHT}

From the result above, it shows that the $\mathrm{t}$ count of the both post-test was3.882 while the $\mathrm{t}$-table is 1.833 . It can be seen that the $\mathrm{t}$ count is higher than the t-table ( $\mathrm{t}$-count $>\mathrm{t}$ table). In addition, the sig.value resulted 0.018 which is lower than the $\alpha$ sig. 0.05 (sig.value $<\alpha$ sig. 0.05). Therefore, Ho6 is rejected, and Ha6 is accepted, which means that there was a significant difference of low motivated students treated using TSI and NHT.
The Result of Each Subject Effect

Tests of Between-Subjects Effects

Dependent Variable: SpeakingSkill

From the result above, it can be seen that the data consist of techniques,

Paired Samples Statistics

\begin{tabular}{|c|c|c|c|c|}
\hline & Mean & $\mathrm{N}$ & $\begin{array}{c}\text { Std. } \\
\text { Deviation }\end{array}$ & $\begin{array}{c}\text { Std. Error } \\
\text { Mean }\end{array}$ \\
\hline Pair 1 Post Exp Low & 79.1667 & 6 & 9.35414 & 4.18330 \\
& & & & \\
$\quad \begin{array}{l}\text { Post Cont } \\
\text { Low }\end{array}$ & 70.0000 & 6 & 4.47214 & 2.00000 \\
\hline
\end{tabular}

motivation, and techniques *motivation. The table shows the F-count result for each source. The first data is techniques, and the result of F-count for the techniques is 32.449. The second, F-count of motivation is 0.090 . The last, F-count of techniques*motivation is 0.090. Meanwhile, the F-table is 4.351. It means that F-count for each source is lower than F-table except the media.To sum up, the media (TSI and NHT) have significant difference on students'speaking skill, but their motivational level did not give any significant difference. All in all, it concludes that $\mathrm{Ho} 7$ is accepted, and $\mathrm{Ha} 7$ is rejected which means that there is no interaction among the techniques, motivation, and speaking skill.

Based on the findings, in general, the discussion goes to explain the effectiveness of TSI and NHT as techniques to teach speaking to students with high and low motivation. However, as it is stated before, taking motivation as a moderator variable in this study, spesifically the discussion of this study concerncs with some hypotheses mentioned in the previous chapter. Those hypotheses are formulated through null hypotheses which will be discussed below. 
There was a significant effect of TSI to teach speaking to high motivated students. It can be concluded that TSI is effective and can be ehanced to high motivated students. In this case, students with high motivation can get significant achievement in their speaking learning. Motivation can activate, direct and sustain goal aimed.

There was a significant effect of TSI to teach speaking to low motivated students. In this case, students with high motivation can get significant achievement in their speaking learning. Eventhough the students have low motivation, they still can get improvement in their speaking learning through TSI.

There wasa significant effect of NHT. In this case, students with high motivation can get significant achievement in their speaking learning. Motivation can activate, direct and sustain goal aimed.

There wasa significant effect of NHT to teach speaking to low motivated students. In this case, students with high motivation can get significant achievement in their speaking learning. Eventhough the students have low motivation, they still can get improvement in their speaking learning through $N H T$.

There wasa significant difference of high motivated students treated using TSI and NHT.

There was a significant difference of low motivated students treated using TSI and NHT. In this case, students with high motivation can get significant achievement in their speaking learning. Eventhough the students have low motivation, they still can get improvement in their speaking learning through the CLT. However, enahncing CLT as a medium to teach speaking is more effective than without enahncing the CLT.

Both techinques are effective to teach speaking without considering their motivational level. This is because motivation has no direct effect and it has no interaction with the technique and students' speaking skill.

Based on the findings and discussion above, it can be concluded that both techinques (TSI and NHT) are effective to teach speaking. However, TSI performs more effective than NHT as teaching technique. Motivation, however, does not give any significant effect for students who are treated using TSI. This proves that proper technique can be enhanced and encourage students' achievement.

Based on the findings and discussion above, it can be concluded that both techinques (TSI and NHT) are effective to teach speaking. However, TSI performs more effective than NHT as teaching technique. Motivation, however, does not give any significant effect for students who are treated using TSI. This proves that proper technique can be enhanced and encourage students' achievement.

\section{Conclusion}

TSI and NHT are effective to teach speaking to high motivated students of Nissan Fortuna English Course Kudus Year 2015/2016. Therefore, these techniques can be used to highly motivated students as a medium of their speaking learning. TSI and NHT are effective to teach speaking to low motivated students. These techniques can also be used to low motivated students as a medium of their speaking learning. TSI is more effective than using NHT to high motivated students. The use of TSI is recomended to enhance speaking skill for those highly motivated students. Teaching speaking using TSI is more effective than using the NHT to low motivated students. The use of TSI still can perform better than NHT as a technique to 
enhance speaking skill to the low motivated students. Therefore, the use of TSI is recomended to enhance speaking skill for those highly motivated students beside NHT in learning process. There is no interaction among the techniques, students' motivation and speaking skill. This means that speaking mastery can be achieved through the techniques (both TSI and NHT) without considering students' motivational level (highly and low motivated students)

It can be concluded that different techniques actually have different effect for enhancing students' speaking skill. Meanwhile, motivational level cannot be considered to have effect in students' speaking skill.

This study implies that both of the techniques (TSI and NHT) are effective to teach students' speaking skill. However, TSI as a technique of Cooperative Learning can perform better than NHT to enhance students' speaking skill. Students can learn speaking actively using those techniques. Therfore, these can be valuable input to teach speaking skill.

The use of the TSI and NHT techniques are able to encourage the students to practice speaking during the teaching and learning process. By applying those techniques, they get more opportunity in interacting with their friends using English and they are also able to enjoy the teaching and learning process. It helps the students to formulate what they want to say. As a result, they are able to explore themselves in expressing their opinions in English. Moreover, it is effective in improving the students' confidence in speaking. This condition improved their involvement in the teaching and learning process. Both techinques are effective to improve students' speaking ability.

For further study, it is suggested to use another method like true experimental or classroom action research where the teacher or the researcher knows better the natural condition of their students without having some random assignment. Also, it is suggested to try another moderator variable like gender or self-esteem. So, this will be a campaign for educational world to enahance teaching and learning using the technique.

\section{References}

Brown, H.D. (2004). Language Assessment: Principles and Classroom Practices. New York: Pearson Education, Inc.

Cooper, J.L. (1995). Cooperative Learning and Critical Thinking. Teaching of Psychology, 22(1), 7-8.

Cooper, J., Robinson, P., and McKinney, M. (1993). Cooperative Learning in The Classroom. San Francisco: Jossey-Bass.

Darsini. (2013). “Improving Speaking Skill through Cooperative Learning Method of the Eighth Grade Students of SMPN 2 Ubud in Academic Year 2012/2013”.

Hidayati, M. (2014). Improving Students' Motivation in Speaking Through a Role Play Technique. Thesis. English Language Education Post Graduate Program Semarang State University. 
Mulyadi. D. (2013). The Effectiveness ofMultimedia Presentation in Improving Students' Speaking Skills (Student Nurse of UNIMUS)eng.edu.unimus@gmail.com

Kagan, S. (1993). Cooperative Learning. San Clemente, CA: Kagan Publications.

Kartika. (2013). Improving Students" Confidence Through Story Telling by Using Script Paired Learning. Thesis. English Language Education Post Graduate Program Semarang State University.

Lie, A. (2008). Cooperative Learning: Mempraktikkan Cooperative Learning di Ruang-Ruang Kelas. Jakarta: PT Grasindo.

Milchatun, Bharati, DALB., Hartono, R. (2015). Improving Students' Personal Self Concept Through Role Play Technique in Teaching Speaking Skill. English Education Journal. http://journal.unnes.ac.id/sju/index.php/eej

Nunan, D. (2003). The Impact of English as a Global Language on Educatinal Policies and Practices in the Asia-Pasific Region TESOL Quarterly 37(4).589-613

Slavin, R.E. et al. (1998). Cooperative Learning: Theory, Research and Practice, United States of America: A Simon \& Schuster Company

Utami, R. (2010). Improving Speaking Skill Using Three - Step Interview in the First Grade of SMA N 1 Ngawi. Thesis. University of Semarang.

Yuliasari, I. (2011). Cooperative Learning Techniques to Improve Students' Translation (a modified form of a paper presented at Asian EFL Journal-Asia TESOL International Seminar Cebu Island, Philippines, August 12-13, 201). LANGUAGE CIRCLE Journal of Language and Literature Vol. VIII/2April 2014.

Yuliasri, I. (2017). Applicability of Cooperative Learning Techniques in Different Classroom Context. International Conference on ELTLT (English Language Teaching Literature, and Translation), pp. 44-53. 